\title{
Feminist foreign policies (FFPs) as strategic narratives: Norm translation in Sweden, Canada, France, and Mexico - ADDENDUM
}

\author{
Ekatherina Zhukova* (D), Malena Rosén Sundström and Ole Elgström \\ Department of Political Science, Lund University, Lund, Sweden \\ *Corresponding author. Email: ekatherina.zhukova@svet.lu.se \\ (First published online 13 September 2021)
}

doi: 10.1017/S0260210521000413. Published by Cambridge University Press, 28 July 2021.

The above article was published with the funding information omitted. The article has been updated to reflect this.

The authors apologise for this error.

\section{Reference}

Zhukova, E., Rosén Sundström, M., \& Elgström, O. 2021. Feminist foreign policies (FFPs) as strategic narratives: Norm translation in Sweden, Canada, France, and Mexico. Review of International Studies X: 1-22. doi:10.1017/ S0260210521000413

\footnotetext{
Cite this article: Zhukova, E., Sundström, M., Elgström, O. 2022. Feminist foreign policies (FFPs) as strategic narratives: Norm translation in Sweden, Canada, France, and Mexico - ADDENDUM. Review of International Studies 48, 217-217. https:// doi.org/10.1017/S0260210521000516

(C) The Author(s), 2021. Published by Cambridge University Press on behalf of the British International Studies Association. This is an Open Access article, distributed under the terms of the Creative Commons Attribution-NonCommercial-NoDerivatives licence (http://creativecommons.org/licenses/by-nc-nd/4.0/), which permits non-commercial re-use, distribution, and reproduction in any medium, provided the original work is unaltered and is properly cited. The written permission of Cambridge University Press must be obtained for commercial re-use or in order to create a derivative work.
} 